\title{
Thermal Effects on Movement Patterns of Yellow Baboons
}

\author{
JEFFREY K. STELZNER \\ Cornell University
}

\begin{abstract}
This paper examines the effect of thermal environment on movement patterns of freeranging yellow baboons (Papio cynocephalus). For Amboseli baboons, one source of potential thermal stress is intense midday heat, and a plausible thermoregulatory response is for animals to simply move into the shade. I therefore examined the hypothesis that baboons would choose quadrats with higher shade availability (as measured by vegetation cover) in response to increasing midday heat loads (as measured by air temperature and solar radiation).

Surprisingly, this was not the case-neither ambient air temperature, ambient solar radiation, nor quadrat plant species composition had a significant effect on shade availability of quadrat selected. Instead, thermal conditions affected a different aspect of baboon movements; namely, spatial displacement rates. At high air temperatures, baboons as a group traversed woodland habitats more slowly, and bare pans more quickly, than at lower air temperatures. I surmised that this relationship might reflect thermal effects on movement patterns at a smaller scale: if individuals exposed to high heat loads spent more time resting in shade under clumps of vegetation, they would thereby traverse densely-vegetated (hence shaded) quadrats more slowly.

To address this question directly, I obtained focal sample data on activity and microhabitat budgets of individual baboons in relation to environmental temperature. The frequency of most combinations of activity state (e.g., grooming, social behavior) and microenvironment state (e.g., elevation, proximity to vegetation) did not vary monotonically with air temperature. However, baboons in shaded locations (but not those in unshaded locations) spent more time resting and less time moving at high air temperatures than low. In other words, baboon activity budgets depended on both microclimate and microhabitat-animals reduced their activity, particularly movement, when they encountered shade under hot conditions. This pattern of microhabitat choice in turn led to temperature-dependent changes in travel rate at the habitat level.

These observational studies of movement patterns suggest that Amboseli baboons employ opportunistic thermoregulation-they do not seek out densely-shaded habitats or individual patches of shade at high air temperatures. Instead, they respond to environmental heat loads by resting, and thereby slowing down, when they happen to encounter plant shade. Aspects of baboon ecology that favor such an opportunistic mode of thermoregulation include large body size and non-thermal constraints on movement patterns.
\end{abstract}

Key Words: Behavior; Thermoregulation; Habitat selection; Biometeorology; Microclimate; Papio; Amboseli National Park.

\section{INTRODUCTION}

Patterns of space use form a central topic in behavioral ecology. Animal movements are typically viewed as a series of habitat choices that maximize ecological benefits relative to costs (AltmanN, 1974; Charnov, 1976; AlCOCK, 1979). In particular, field studies of baboon ranging behavior (PosT, 1978; ANDERSON, 1982) have emphasized food availability as the primary benefit, and predation risk the primary cost involved in habitat choice. Thermal costs and benefits, in contrast, have received less attention (HUEY \& SLATKIN, 1976; SHARMAN, 
1980 ; Iwamoto \& DunBar, 1983). Several lines of evidence, however, suggest that thermoregulation plays a greater role than previously thought.

Primates in natural environments alter their activity schedules according to thermoregulatory needs (Altmann \& Altmann, 1970; Stolz \& Saymann, 1970; Bernstein, 1972, 1975, 1976; DAHL et al., 1982; DAHL \& SMITH, 1985). Laboratory studies (ADAIR \& WRIGHT, 1976; ADAIR, 1977) show that primates are extremely sensitive to thermal changes; air temperature differences as small as $1^{\circ} \mathrm{C}$ can trigger operant thermoregulatory responses. On the other hand, subjects tolerate greater temperature variation as temperature control tasks are made more difficult. Since primates such as rhesus monkeys (FOLK, 1966) can withstand dry bulb temperatures of up to $44^{\circ} \mathrm{C}$ without becoming hyperthermic, it appears that behavioral thermoregulation mechanisms are invoked well within the critical thermal envelope of physiological tolerance. On this basis, one could argue that the primary thermal constraints on behavior are likely to be ecological, rather than physiological.

ADAIR and WRIGHT (1976) propose that behavioral thermoregulation in mammals minimizes both energy expenditure and thermal stress, an hypothesis that remains to be tested in the field. From an ecological viewpoint, energy expenditure is only one of several costs associated with physiological thermoregulation in primates; in particular, additional costs may also be associated directly or indirectly with water loss. The thermal neutral zone (TNZ) in Macaca mulatta spans an approximate range of ambient temperatures between $25-30^{\circ} \mathrm{C}$ (ELIZONDO, 1977): below $25^{\circ} \mathrm{C}$, resting metabolic rate (RMR) increases as ambient temperature decreases; above $30^{\circ} \mathrm{C}$, cutaneous and respiratory evaporative water loss (EWL) rise sharply as temperatures approach $40^{\circ} \mathrm{C}$.

When baboons (Papio cynocephalus) are subjected to $70-120 \mathrm{~min}$ of heat exposure at $40^{\circ} \mathrm{C}$, following acclimatization at $18^{\circ} \mathrm{C}$, rectal temperatures rise $0.6-1.5^{\circ} \mathrm{C}$, respiratory rate increases $\simeq 65 \%$, and cutaneous water loss increases $\simeq 362 \%$ (HILEY, 1976). Data from other laboratory studies of heat stress in baboons (NEWMAN et al., 1970; FunKHOUSER et al., 1967) indicate that roughly $80 \%$ of total evaporative cooling in baboons is due to cutaneous (as opposed to more efficient respiratory) water loss, over a wide range of environmental humidity. Yellow baboons in Amboseli have access to water at several permanent waterholes scattered throughout their home range. However, to the extent that ecological costs (e.g., travel time, predation risk at waterholes) are associated with drinking, evaporative water loss may yet represent an indirect, but significant physiological cost derived from thermoregulation.

Despite growing theoretical interest, few ecological studies have addressed behavioral thermoregulation in mammals (RusSell, 1971; ZeRvanos \& HADLeY, 1973; MoRHaRdT \& Gates, 1974; Ingram \& Legge, 1971). Nevertheless, biophysical models (Porter et al., 1973; Porter \& James, 1979; Bakken, 1976; Gates, 1980; Porter \& Tracy, 1983) clearly demonstrate that small-scale microhabitat differences can significantly alter heat exchange and consequent metabolic energy costs. Vegetation in particular alters local wind flows, shade, and humidity (CAMPBELL, 1977); clumps of vegetation thus often serve as thermal refuges for animals (Dewoskin, 1980; Gates \& Harman, 1980; Kelty \& Lustick, 1977). These lines of evidence suggest that baboons can behaviorally thermoregulate, and thereby reduce physiological costs, by selectively positioning themselves near trees and shrubs.

This study examined thermal effects on movement patterns in free-ranging yellow baboons (Papio cynocephalus) in Amboseli National Park, Kenya. In the laboratory, baboons exhibit predictable physiological responses to heat stress (HILEY, 1976). Further, a preliminary climate space analysis (CHAPPELL, pers. comm.) indicated that Papio may not be able to 
maintain steady-state heat balance under typical midday thermal conditions. Specifically, given conservative estimates of baboon thermal characteristics (mass $\simeq 15 \mathrm{~kg}$, surface area $\simeq 0.6 \mathrm{~m}^{2}$, absorptivity $\simeq 0.75$, insulation $\simeq 140 \mathrm{~cm}^{2 .}{ }^{\circ} \mathrm{C} \cdot \mathrm{min} \cdot \mathrm{cal}^{-1}$ ) and physiological state [basal metabolic rate, moderately elevated body temperature $\left(40^{\circ} \mathrm{C}\right)$ maximal evaporative water loss], baboons exposed to environmental conditions of clear sky, full sun, and low windspeeds $\left(0.1-1.0 \mathrm{~m} \cdot \mathrm{sec}^{-1}\right)$ should experience net heat gain at air temperatures above 15 $20^{\circ} \mathrm{C}$. In deep shade, on the other hand, steady-state net heat balance should be possible at air temperatures up to $40^{\circ} \mathrm{C}$.

This a priori information suggested that these savannah baboons, when exposed to warm midday sun, should preferentially move into the shade generated by shrubs and trees. Specifically, I predicted that as heat loads increased, baboons would increasingly select habitats with more plant cover, and would spend more time in shaded microhabitats near clumps of vegetation.

\section{SUBJECTS AND METHODS}

\section{StUdy Site}

Data for this report were collected in Amboseli National Park, Kenya, during JanuaryNovember 1979. The study area consisted mainly of short-grass savannah, with permanent swamps and waterholes fed by runoff from nearby Mt. Kilimanjaro. Tree species diversity was low, vegetation was typically clumped, and boundaries between plant associations were abrupt (Western, 1972; Western \& Van Praet, 1973; Post, 1978).

Amboseli weather is equatorial, with more seasonality in rainfall than in temperature (GRIFFITHS, 1969). In 1979, total monthly rainfall averaged $36.1 \pm 38.2 \mathrm{~mm}$ (mean \pm 1 S.D.); monthly maximum air temperature averaged $29.0 \pm 1.58^{\circ} \mathrm{C}$, minimum air temperature $12.8 \pm$ $2.15^{\circ} \mathrm{C}$. Hence, baboons faced cool temperatures (and potential heat loss) each morning, yet faced high temperatures (and potential heat gain) during the midday.

\section{SubJECTs}

Behavioral data were collected from a group of approximately 46 free-living yellow baboons. All individuals were habituated to human observers at close range, and had not been provisioned or experimentally manipulated in any fashion. Aspects of the ecology and foraging behavior of this population have been previously described (ALTMANN \& ALTMANN, 1970; Slatkin \& Hausfater, 1976; Post, 1978; Post et al., 1980).

\section{Data Collection Procedures}

For the purpose of analyzing baboon movements, I partitioned the study group's home range into a grid of rectangular quadrats, as described below. In the course of their day journeys, baboons moved between quadrats of vastly different plant cover and, presumably, shade availability. To examine the effects of thermal conditions and shade availability on behavior, I collected data on (1) plant cover within each quadrat of the home range, (2) the sequence of quadrats traversed by the baboon group, (3) activity and microhabitat schedules of individuals, and (4) prevailing thermal conditions. 


\section{Plant Cover}

Because Amboseli vegetation forms discrete zones, I estimated plant cover within the group home range via stratified sampling (Post, 1978). During September and October 1979, I classified vegetation zones into seven categories based on plant height and physiognomy, and mapped all zone boundaries on calibrated aerial photographs $(1: 14812.56$ scale $)$ following the method of ALTMANN and ALTMANN (1970). Bare pan areas greater than $25 \mathrm{~m}$ in radius were mapped as separate zones; smaller bare patches were ignored.

Within each vegetation zone, I used line-transect samples to estimate two measures of plant cover for plants $1 \mathrm{~m}$ or more in height: percent cover and stem density. Samples were taken at $200 \mathrm{~m}$ intervals along randomly-chosen transect lines within the study group's 1979 home range until each vegetation zone had been sampled exactly 12 times. Bare pan (BP) zones contained by definition no vegetation $1 \mathrm{~m}$ or greater in height, and were not sampled.

At each sample location I obtained Bitterlich variable-plot estimates of percent cover for four plant categories and point-center quarter (PCQ) estimates of and stem density for six plant categories (Clark \& Evans, 1954; CotTam \& Curtis, 1956; Grieg-Smith, 1965; Mueller-Dombois \& Ellenberg, 1974). PCQ distances were determined via measuring tape or optical rangefinder (Wild Heerbrugg 1078); values greater than $305 \mathrm{~m}$ were lumped into a single category. Corrected mean densities used in this report were computed via the methods of WARDE and PeTranKa (1981). Bitterlich measurements were obtained via a calibrated sighting instrument. A field assistant marked plants hidden from direct view, and these were included in Bitterlich counts.

For analytical purposes I digitized the vegetation zone map as a matrix of arbitrarily-small $(58.5 \mathrm{~m} \times 97.5 \mathrm{~m})$ quadrats, each classified by its zone of largest total area (SYMAP v5.20, Harvard Laboratory for Computer Graphics and Spatial Analysis, Cambridge, Massachusetts). Vegetation zones were significantly larger on average than quadrats (5.59 ha vs. $0.57 \mathrm{ha}$ ), hence classification errors were unlikely.

\section{Quadrat Selection}

Behavioral data were collected on a near-daily basis, whenever observers were in visual contact with the study group. On each sampling day, observers located the group prior to group descent from sleeping trees (generally 06:30-09:30), and remained in contact through the time of group ascent in the evening (generally 17:30-18:30). At half-hour intervals, observers marked the estimated center-of-mass of the study group on aerial photographs.

The coordinates of each point were digitized and uniquely associated with a quadrat on the vegetation zone map. Baboon groups typically occupied areas smaller than a single quadrat $(0.57 \mathrm{ha})$. Each map quadrat selected by the group was treated as a point sample of habitat selection based on thermal conditions and plant cover. Data for this report are based on a total of $331 \mathrm{hr}$ of contact over 81 days of sampling.

\section{Thermal Environment}

Thermal sampling procedures were designed to quantify heat loads on baboons. Toward this end, temperature measurements were taken $30 \mathrm{~cm}$ above ground, the approximate midtrunk height of an adult baboon, except as noted below. Further, instruments were positioned in an unshaded area free of vegetation, to minimize any microclimatic effects due to vegetation or terrain. 
Air temperature $\left(T_{\mathrm{air}}\right)$ and blackbulb temperature $\left(T_{\mathrm{bb}}\right)$ were recorded to the nearest $0.2^{\circ} \mathrm{C}$ via an Omega $2175 \mathrm{~A}$ digital thermocouple thermometer equipped with a fast-response copper-constantan probe. The $T_{\mathrm{air}}$ probe was shaded by a ventilated aluminum shield, while the $T_{\mathrm{bb}}$ thermocouple was enclosed in a flat-black copper bulb $11.4 \mathrm{~cm}$ in diameter. Maximum daily air temperature $\left(T_{\max }\right)$ was recorded to the nearest $0.5^{\circ} \mathrm{C}$ via a Taylor mercury min-max thermometer mounted in a shaded location $2 \mathrm{~m}$ above ground. Total downwelling solar radiation $\left(S R_{\text {tot }}\right)$ was measured to the nearest $1.0 \mathrm{~W} \cdot \mathrm{m}^{-2}$ via a LiCor pyranometer equipped with a cosine-corrected silicon radiation sensor. The sensor was attached to a flat board which was placed on the ground and levelled by means of an attached bubble level.

\section{Activity/Microhabitat Budgets}

I monitored individual activities and microhabitat selection via focal animal samples (Altmann, 1974). A total of 16 animals were used for sampling: 5 adult females, 6 adult males, 3 juvenile-1 females, and 2 juvenile-1 males. Age class definitions follow those of ALTMANN et al. (1981). Adults occupied the maximum, median, and minimum dominance rank positions within their age-sex class, based on ad lib. samples of agonistic interactions. Six different focal targets were sampled each day: two adult females, two adult males, one juvenile-1 female, and one juvenile-1 male. Dominance criteria follow HaUsfater (1975). Juveniles were selected at random. In the event that a primary focal target was lost through injury, death, or emigration, an alternate was chosen using identical criteria.

Samples were taken during two of three time blocks $(09: 00-11: 59,12: 00-14: 59,15: 00-18$ : $00)$ per day, on a rotating schedule. Focal samples started on the hour, and were of $20 \mathrm{~min}$ duration. If a focal target could not be located, sampling instead began on the next available 5 -min mark. Focal samples were randomized by time of day on a rotating schedule. Data for this report are based on 399 focal samples.

In each focal sample I recorded the elapsed time of each activity and microhabitat transition by the target, where microhabitats were classified by shade, elevation, and vegetation proximity. An animal's activity/microenvironment state was therefore a function of four state variables: A (activity), $\mathrm{S}$ (shade), $\mathrm{E}$ (elevation), and $\mathrm{V}$ (vegetation proximity). Elapsed time data from focal samples were converted to equivalent sequences of state vectors $(\mathrm{A}=a$, $\mathrm{S}=s, \mathrm{E}=e, \mathrm{~V}=v$ ) representing an animal's activity/microenvironment state at any given point in time. For each focal sample I considered all pairwise combinations of state variable values $(x, y)$, where $x=a, s, e$, or $v ; y=a, s, e$, or $v$; and $x \neq y$. I then computed the conditional proportion of time $p(y \mid x)$ spent in activity or microenvironment $y$ given concurrent occupancy of activity or microenvironment $x$. For example, one such combination would represent the proportion of time spent in the shade given that an animal was also within $50 \mathrm{~cm}$ of a plant.

To examine thermal effects on microhabitat choice, I grouped samples into $5^{\circ} \mathrm{C}$ temperature categories, then plotted median conditional proportions versus temperature. Associations were scored as significant if medians varied monotonically with temperature and $90 \%$ confidence intervals did not overlap. To compensate for inherent bias in the data toward extreme proportions $(0.0$ and 1.0$)$, which obscured trends at intermediate proportion values, I analyzed a reduced dataset in which values of 0.0 or 1.0 were excluded (i.e., samples in which at least one state transition occurred). Statistical models were evaluated via SAS (SAS Institute, Cary, North Carolina) and Minitab (Minitab Inc., University Park, Pennsylvania) analysis packages. 


\section{RESULTS}

\section{Plant Cover}

Table 1 lists percent cover by plant category for each zone, along with the relative area of each vegetation zone within the home range, expressed as a percentage. On the basis of total percent cover, zones fell into three shade categories: low $(0-5 \%)$, medium $(5-10 \%)$, and high shade ( $10 \%$ and above). Low-shade zones were comprised of grasslands and bare pan. Highshade zones included the mature and sapling woodlands, while dead woodlands offered intermediate shade. As one might expect in an open savannah, low-shade zones predominated over high-shade zones $(62.4 \%$ vs. $17.0 \%)$. Table 2 lists corresponding values for stem density, which followed the same general patterns as percent cover. Shrubs, as a rule, comprised the majority of plant cover, followed by the predominant tree species in each woodland.

\section{Group Quadrat Choice}

Conceptually, the daily movements of the study group consisted of a series of quadrat choices made under ever-changing thermal conditions. At the same time, baboons were necessarily choosing specific levels of plant cover and shade, according to the vegetation

Table 1. Percent cover estimates by plant category and vegetation zone, in decreasing order of total percent cover.

\begin{tabular}{lllllll}
\hline Vegetation & \multirow{2}{*}{$\begin{array}{l}\text { Relative area } \\
\text { zone }\end{array}$} & \multicolumn{2}{c}{ Plant category } & & & s \\
\cline { 3 - 7 } & $(\%)$ & axm & axs & atm & ss & Total \\
\hline SAX & 2.08 & 0.63 & 6.10 & 0.20 & 7.15 & 14.080 \\
MAX & 4.76 & 3.08 & 1.42 & 0.32 & 6.98 & 11.800 \\
MAT & 10.15 & 0.35 & 0.07 & 4.18 & 5.57 & 10.170 \\
DAW & 20.62 & 0.10 & 0.20 & 0.17 & 4.80 & 5.270 \\
SCG & 7.05 & 0.18 & 0.02 & 0.10 & 2.33 & 2.630 \\
MSG & 40.79 & 0.03 & 0.03 & 0.08 & 0.23 & 0.370 \\
BP & 14.55 & 0.00 & 0.00 & 0.00 & 0.00 & 0.000 \\
\hline
\end{tabular}

Relative areas (percent total home range area) also listed for each vegetation zone. Values derived from Bitterlich estimates $\left(N=12 \cdot\right.$ zone $\left.^{-1}\right)$. Symbols used in Tables 1 and 2: Vegetation zones: SAX = Sapling Acacia xanthophloea woodland; MAX = Mature Acacia xanthophloea woodland; MAT = Mature Acacia tortilis woodland; DAW = Dead Acacia woodland $\mathbf{S C G}=$ Sporobolus consimilis grassland; $\mathrm{MSG}=$ Mixed species grassland; $\mathbf{B P}=$ Bare pan. Plant categories: axs = Sapling Acacia xanthophloea; axm = Mature Acacia xanthophloea $;$ atm = Mature Acacia tortilis; ss = Shrub spp.; sc $=$ Sporobolus consimilis $;$ asd $=$ Dead Acacia wood.

Table 2. Stem density estimates by plant category and vegetation zone, corrected PCQ estimate $\mathrm{D}_{\mathrm{c}}$ (individuals $\cdot \mathrm{ha}^{-1}, N=48 \cdot \mathrm{zone}^{-1}$ ).

\begin{tabular}{llllllll}
\hline \multirow{2}{*}{$\begin{array}{l}\text { Vegetation } \\
\text { zone }\end{array}$} & \multicolumn{2}{l}{ Plant category } & \multicolumn{2}{l}{} & \\
\cline { 2 - 8 } & axm & axs & atm & ss & sc & asd & Total \\
\hline SAX & 0.2073 & 11.26 & 0.0443 & 7.646 & 2.569 & 1.136 & 22.863 \\
MAX & 1.484 & 0.2303 & 0.1686 & 14.03 & 2.275 & 3.830 & 22.018 \\
MAT & 0.1388 & 0.1003 & 1.598 & 3.460 & 0.1202 & 4.508 & 9.925 \\
DAW & 0.0699 & 0.1186 & 0.2291 & 16.52 & 0.6107 & 5.383 & 22.931 \\
SCG & 0.0373 & 0.1606 & 0.0365 & 3.166 & 26.30 & 0.8448 & 30.545 \\
MSG & 0.0482 & 0.1024 & 0.1971 & 0.7231 & 0.2424 & $\mathbf{0 . 5 1 0 9}$ & 1.824 \\
BP & 0.00 & 0.00 & 0.00 & 0.00 & 0.00 & 0.00 & 0.000 \\
\hline
\end{tabular}

Symbols as in Table 1 . 
characteristics of the quadrat. On thermoregulatory grounds, I initially predicted that baboons would prefer densely-vegetated (i.e., high-shade) quadrats when subjected to high environmental heat loads.

To test this idea, I examined a general linear model (GLM) of quadrat choice in relation to shade availability and heat load, controlling for time-of-day. Lacking a priori information on the relationship between shade distribution and its effective availability, I contrasted two measures: (a) total shaded area (plant percent cover) and (b) the number of individual shade sites, regardless of size (plant stem density). Similarly, I also contrasted four measures of heat load, as listed below. The specific form of the GLM model was:

$$
S=\beta_{0}+\beta_{1}(H)+\beta_{2}(T)+\beta_{3}(H \cdot T)+e,
$$

where $S=$ shade availability in quadrats used by baboons, measured as either (a) percent cover or (b) stem density, summed across all tree and shrub species. $H=$ heat load, measured as (a) $T_{\mathrm{air}}$, (b) $T_{\mathrm{max}}$, (c) $T_{\mathrm{bb}}$, or (d) $S R_{\mathrm{tot}}$; $\mathrm{T}=$ time block, $1=09: 00-11: 59,2=12: 00$ 14:59, $3=15: 00-18: 00 ;(H \cdot T)=$ interaction term for $H$ nested within $T ; e=$ error term.

A key point to emphasize is that the dependent variable in this model, shade availability, in fact measured a behavioral response, namely choice of quadrats with specified levels of shade. In all, I evaluated eight GLM models, representing all combinations of the two shade availability measures (percent cover and stem density) with the four microclimate measures $\left(T_{\mathrm{air}}, T_{\mathrm{max}}, T_{\mathrm{bb}}\right.$, and $\left.S R_{\mathrm{tot}}\right)$. In no case was there a statistically significant linear relationship between heat load on the one hand and shade-dependent quadrat choice on the otherthe $r^{2}$ values for these models ranged between 0.00848 and 0.03194 . In other words, the study group moved between quadrats of different shade characteristics without apparent regard for temperature or solar radiation.

I reasoned, however, that two factors might act to confound the GLM analysis. First, the model's assumption of linearity would not hold if baboons responded only to relatively extreme heat loads. A related study had shown (STELZNER \& HAUSFATER, 1986) that baboons respond in just such a nonlinear fashion to thermal conditions during the early morning. Second, the GLM analysis did not measure choice among all potentially-available quadrats, but rather only those quadrats actually selected by baboons. This could have led to a biased quadrat sample if preferences based on, say, food plants, masked temperature-based preferences.

To address the linearity problem I turned to contingency table analysis. Briefly, I classified quadrat occupancy point samples into three air temperature categories: below $\left(T_{\mathrm{air}}<25^{\circ} \mathrm{C}\right)$, within $\left(25^{\circ} \mathrm{C} \leq T_{\mathrm{air}} \leq 30^{\circ} \mathrm{C}\right)$ and above $\left(T_{\mathrm{air}}>30^{\circ} \mathrm{C}\right)$ the approximate thermal neutral zone (TNZ) for baboons (ELIZondo, 1977). Time-of-day effects were not considered as in GLM analyses, in order to maintain adequate sample sizes. Next, to address the problem of bias in the quadrat sample, I computed expected quadrat occupancy frequencies based solely on the proportional area of each quadrat type, and compared these to observed values. Specifically, I computed two sets of expected values under different assumptions: on the one hand, that all quadrats in the home range were equally accessible, irrespective of group position; on the other, that only nearby quadrats were effectively accessible by baboons.

Table 3 displays $\chi^{2}$ results based on all quadrats within the home range, while Table 4 considers only quadrats lying within the mean half-hour cruising radius $(306.6 \mathrm{~m})$ of each group location. The magnitude of each table entry corresponds to $\chi^{2}$, while the sign denotes the sign of the quantity (observed-expected). Table 3 shows that baboons did not encounter 
Table 3. Quadrat occupancy frequencies by vegetation zone by air temperature category and across all temperatures (All).

\begin{tabular}{|c|c|c|c|c|c|c|c|c|}
\hline \multirow{2}{*}{$\begin{array}{l}\text { Air temperature } \\
\text { category }\end{array}$} & \multicolumn{8}{|c|}{ Vegetation zone } \\
\hline & MAX & SAX & DAW & MAT & SCG & MSG & BP & $N$ \\
\hline$T_{\text {air }}<25^{\circ} \mathrm{C}$ & $\begin{array}{r}+3.97 \\
5.38\end{array}$ & $\begin{array}{r}-0.05 \\
2.35\end{array}$ & $\begin{array}{r}-5.48 \\
23.30\end{array}$ & $\begin{array}{r}-1.74 \\
11.47\end{array}$ & $\begin{array}{r}-6.09 \\
7.97\end{array}$ & $\begin{array}{r}+13.46 \\
46.09\end{array}$ & $\begin{array}{r}-2.52 \\
16.44\end{array}$ & 113 \\
\hline $25^{\circ} \mathrm{C} \leq T_{\mathrm{air}} \leq 30^{\circ} \mathrm{C}$ & $\begin{array}{r}+27.56 \\
13.04\end{array}$ & $\begin{array}{r}+9.35 \\
5.70\end{array}$ & $\begin{array}{r}-0.54 \\
56.50\end{array}$ & $\begin{array}{r}-14.11 \\
27.81\end{array}$ & $\begin{array}{r}-1.46 \\
19.32\end{array}$ & $\begin{array}{r}+2.98 \\
111.76\end{array}$ & $\begin{array}{r}-4.82 \\
39.87\end{array}$ & 274 \\
\hline$T_{\mathrm{a}, \mathrm{ir}}>30^{\circ} \mathrm{C}$ & $\begin{array}{r}+4.78 \\
13.09\end{array}$ & $\begin{array}{r}+18.48 \\
5.72\end{array}$ & $\begin{array}{r}-2.02 \\
56.70\end{array}$ & $\begin{array}{r}-1.71 \\
27.91\end{array}$ & $\begin{array}{r}-2.81 \\
19.39\end{array}$ & $\begin{array}{r}+9.03 \\
112.17\end{array}$ & $\begin{array}{r}-15.64 \\
40.01\end{array}$ & 275 \\
\hline All & $\begin{array}{r}+31.47 \\
31.51\end{array}$ & $\begin{array}{r}+21.56 \\
13.77\end{array}$ & $\begin{array}{r}-5.54 \\
136.50\end{array}$ & $\begin{array}{r}-14.48 \\
67.19\end{array}$ & $\begin{array}{r}-8.29 \\
46.67\end{array}$ & $\begin{array}{r}+20.81 \\
270.03\end{array}$ & $\begin{array}{r}-21.32 \\
96.32\end{array}$ & 662 \\
\hline
\end{tabular}

Lower cell value of pair denotes expected value, computed as product of row total for observed frequencies and mean proportions of each vegetation zone for all quadrats within home range. Upper cell value of each pair is component of $\chi^{-2}$, where sign denotes sign of quantity (observed-expected). Vegetation zone symbols as in Table 1.

Table 4. Quadrat occupancy frequencies by vegetation zone by air temperature category and across all temperatures (All).

\begin{tabular}{|c|c|c|c|c|c|c|c|c|}
\hline \multirow{2}{*}{$\begin{array}{l}\text { Air temperature } \\
\text { category }\end{array}$} & \multicolumn{8}{|c|}{ Vegetation } \\
\hline & MAX & SAX & DAW & MAT & SCG & MSG & BP & $N$ \\
\hline$T_{\mathrm{air}}<25^{\circ} \mathrm{C}$ & $\begin{array}{r}+0.04 \\
9.41\end{array}$ & $\begin{array}{r}-0.25 \\
2.84\end{array}$ & $\begin{array}{r}-0.01 \\
12.42\end{array}$ & $\begin{array}{r}+0.98 \\
4.83\end{array}$ & $\begin{array}{r}-2.56 \\
4.33\end{array}$ & $\begin{array}{r}+0.14 \\
62.07\end{array}$ & $\begin{array}{r}-0.15 \\
8.10\end{array}$ & 104 \\
\hline $25^{\circ} \mathrm{C} \leq T_{\mathrm{air}} \leq 30^{\circ} \mathrm{C}$ & $\begin{array}{r}-0.17 \\
33.39\end{array}$ & $\begin{array}{r}+0.34 \\
10.14\end{array}$ & $\begin{array}{r}+0.47 \\
42.51\end{array}$ & $\begin{array}{r}+0.16 \\
6.95\end{array}$ & $\begin{array}{r}-1.39 \\
16.83\end{array}$ & $\begin{array}{l}-0.17 \\
133.76\end{array}$ & $\begin{array}{r}+0.94 \\
22.42\end{array}$ & 266 \\
\hline$T_{\mathrm{air}}<30^{\circ} \mathrm{C}$ & $\begin{array}{r}+0.80 \\
18.18 \\
\end{array}$ & $\begin{array}{r}+3.39 \\
10.92\end{array}$ & $\begin{array}{r}0.00 \\
50.35\end{array}$ & $\begin{array}{r}+0.14 \\
19.34\end{array}$ & $\begin{array}{r}-1.21 \\
18.76\end{array}$ & $\begin{array}{r}+0.01 \\
149.13\end{array}$ & $\begin{array}{r}-2.41 \\
22.34\end{array}$ & 289 \\
\hline All & $\begin{array}{r}+0.07 \\
60.95\end{array}$ & $\begin{array}{r}+2.12 \\
23.89\end{array}$ & $\begin{array}{l}+0.13 \\
105.28\end{array}$ & $\begin{array}{r}+0.76 \\
31.13\end{array}$ & $\begin{array}{r}-4.18 \\
39.91\end{array}$ & $\begin{array}{r}0.00 \\
344.99\end{array}$ & $\begin{array}{r}-0.28 \\
52.85\end{array}$ & 659 \\
\hline
\end{tabular}

Cell contents as listed for Table 3. Expected values computed as product of row total for observed frequencies and mean proportions of each vegetation zone for quadrats within $306.6 \mathrm{~m}$ of group location at each halfhour. Vegetation zone symbols as in Table 1.

quadrats according to their representation across the entire home range. Instead, there was a strong association between vegetation zone and air temperature $\left(\chi_{\text {total }}^{2}=148.61, d f=\right.$ $12, p<0.005)$; baboons did not clearly show greater preference for high-shade quadrats (e.g., MAX, SAX, and MAT), nor less preference for low-shade quadrats (e.g., MSG), at high air temperatures compared to low.

When only nearby quadrats were considered (Table 4) there was no significant association between temperature and vegetation zone $\left(\chi_{\text {total }}^{2}=15.72, d f=12, p>0.10\right)$. In other words, the apparent association observed on a global scale (the home range as a whole) disappeared on the local scale of quadrats within cruising range: under the latter, more reasonable hypothesis, baboons occupied nearby quadrats simply in proportion to their relative area. Tables 3 and 4 would seem to indicate that temperature did not strongly influence quadrat choice. However, the analyses to this point implicitly assumed that baboons encountered shade in direct proportion to plant density, i.e., that baboons moved more or less randomly at a constant rate through all quadrats. I next relaxed this assumption, and examined the relationship between temperature and between-quadrat differences in travel rate.

\section{Group Travel Rate}

For each day journey, I computed Euclidean distances between successive half-hour group 
Table 5. Net group displacement rate $\left(\mathrm{m} \cdot \mathrm{hr}^{-1}\right)$ by vegetation zone by air temperature category and across all temperatures (All).

\begin{tabular}{lllllllll}
\hline \multirow{2}{*}{$\begin{array}{l}\text { Air temperature } \\
\text { category }\end{array}$} & \multicolumn{2}{l}{ Vegetation zone } & & & & \\
\hline & MAX & SAX & DAW & MAT & SCG & MSG & BP & $N$ \\
\hline$T_{\text {air }}<25^{\circ} \mathrm{C}$ & 572 & 990 & 590 & 619 & & 779 & 569 & 79 \\
$25^{\circ} \mathrm{C}<T_{\text {air }}<30^{\circ} \mathrm{C}$ & 284 & 975 & 397 & 764 & 898 & 637 & 430 & 218 \\
$T_{\text {air }}>30^{\circ} \mathrm{C}$ & 406 & 598 & 439 & 430 & 776 & 702 & 676 & 251 \\
\hline All & 361 & 773 & 439 & 536 & 830 & 690 & 527 & 548 \\
\hline
\end{tabular}

Periods denote cells with missing values (no data).

location coordinates, and converted these to displacement rates $(\mathrm{m} \cdot \mathrm{hr}-1)$. Table 5 shows that overall, the study group traveled most slowly $\left(361 \mathrm{~m} \cdot \mathrm{hr}^{-1}\right)$ when entering mature Acacia xanthophloea woodland, and most quickly $\left(830 \mathrm{~m} \cdot \mathrm{hr}^{-1}\right)$ when entering Sporobolus consimilis grassland. If baboons were responding to environmental heat loads by stopping to rest in shade, one would expect to see lower displacement rates in quadrats of greater shade density.

I tested this idea by comparing displacement rates using Duncan's multiple range test on an ANOVA model with two main effects: temperature category and vegetation zone. To maintain adequate sample sizes, I did not explicitly control for time-of-day effects, which were insignificant in previous analyses. Based on this test, temperature exerted a significant effect across all zones combined: displacement rates were significantly lower for temperatures in the range $T_{\mathrm{air}} \geq 25^{\circ} \mathrm{C}$ compared to the range $T_{\mathrm{air}}<25^{\circ} \mathrm{C}(\alpha=0.05, F=4.70, N=636)$. I therefore grouped the two temperature categories above $25^{\circ} \mathrm{C}$ to examine the effect of vegetation zone on displacement rates. The results indicated that displacement rates varied as a function of vegetation zone only at high air temperatures, not at low temperatures. Specifically, for $T_{\mathrm{a} \text { ir }} \geq 25^{\circ} \mathrm{C}$ group displacement rates fell into three significantly different groups: fast (766.7 $\left.\mathrm{m} \cdot \mathrm{hr}^{-1}\right)$ in Sporobolus consimilis grassland; medium (473.6-614.4 $\mathrm{m} \cdot \mathrm{hr}^{-1}$ ) in mixed species grassland, sapling Acacia xanthophloea woodland, and bare pan; and slow (279.1-350.8 $\left.\mathrm{m} \cdot \mathrm{hr}^{-1}\right)$ in mature Acacia tortilis woodland, dead Acacia woodland, and mature Acacia xanthophloea woodland ( $\alpha=0.05, F=6.23, N=259)$. No such zone-dependent effects were seen at low air temperatures $\left(T_{\mathrm{air}}<25^{\circ} \mathrm{C}\right)$. Thus, only at high temperatures and in woodland quadrats of high plant cover did group displacements decrease-implying that baboons as a group moved more slowly and/or in a less directed fashion.

I surmised that this relationship might reflect thermal effects on movement patterns at a smaller scale; if individuals subjected to high heat loads increased the proportion of time spent resting while located near individual clumps of vegetation, they would thereby traverse densely-vegetated (hence high-shade) quadrats more slowly.

Two cost/benefit arguments supported this idea. First, a shift in activity budget would involve less energetic cost than movement into another vegetation zone. Second, the shade of a single tree or shrub could create a much larger local drop in temperature (i.e., thermal benefit) than would exist between high-shade vs. low-shade quadrats. Concerning this point, when air temperature differences near tree and shrub species in the study area are weighted by corresponding percent cover values (Table 1), the mean difference between quadrats varies only between $0.00-0.59^{\circ} \mathrm{C}$ for ambient temperatures in the range $35.0-40.0^{\circ} \mathrm{C}$ (STELZNER, 1987). Similarly, solar radiation varies only between $0-103 \mathrm{~W} \cdot \mathrm{m}^{-2}$ under ambient loads of $1200-1400 \mathrm{~W} \cdot \mathrm{m}^{-2}$. Thus, baboons may choose to exploit the more cost-effective shade of nearby individual plants rather than relocating themselves into high-shade quadrats. To address this question directly, I obtained focal sample data on activity and microhabitat budgets of individual baboons in relation to environmental temperature. 


\section{Focal Activity/Microhabitat Budgets}

The frequencies of most combinations of activity state (e.g., inactivity, grooming, walking) and microenvironment state (e.g., degree of shade, elevation, proximity to vegetation) did not depend on air temperature. Specifically, baboons showed no increased preference for shaded sites, aboveground sites, or sites near vegetation at high air temperatures vs. low. Similarly, baboons did not significantly reduce their overall level of activity in response to high temperatures.

However, two measures of activity/microhabitat state did vary significantly as a function of air temperature: the conditional probability of inactivity increased with increasing air temperature, while the conditional probability of movement decreased, given that the subject occupied a shaded location (Fig. 1). Thus, an individual's activity budget changed only at times when it occupied a shaded location.

Significantly, no such relationship held for the inverse conditional probability; namely, the proportion of time spent in shade given that the subject was engaged in any particular activity state. This indicates that baboons were not specifically seeking out shaded locations, but rather were responding to opportunistic encounters by altering their activity time budget. Further, there was no effect of temperature on the proportion of time spent in a particular activity state given proximity to vegetation; in other words, shade, rather than some other vegetation-related factor, appeared to be responsible for the temperature-dependent effects on inactivity and movement. Separate analysis showed that activity and microhabitat choices were independent of time-of-day; thus, temperature effects were not simply due to correlation between air temperature and time-of-day. In summary, during the hottest parts of the midday baboons responded to opportunistic encounters with plant shade by spending more time resting and less time moving.

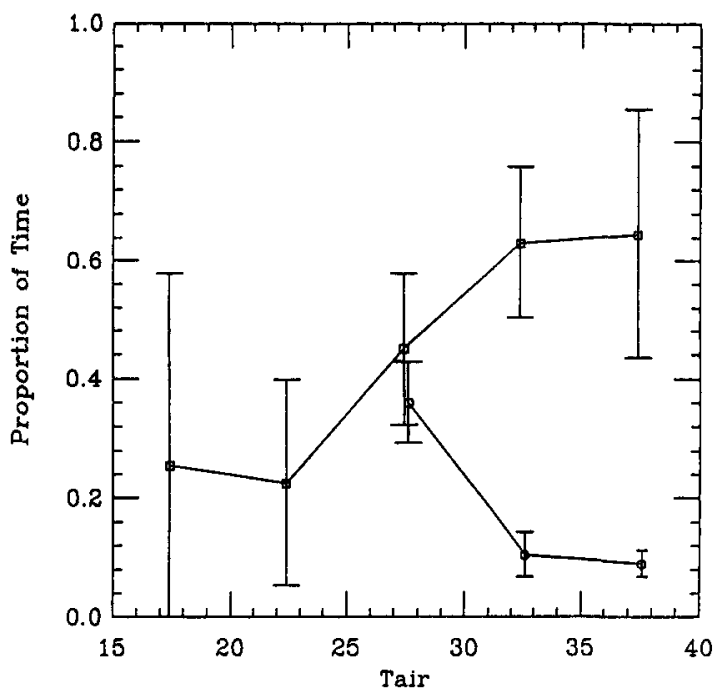

Fig. 1. Activity/microenvironment state in relation to air temperature category. Squares denote conditional proportion of time spent in activity state "inactive" given microenvironment state "extensive shade." Circles denote corresponding values for activity state "move." Error bars denote 90\% nonparametric confidence interval around median proportions. Temperatures in ${ }^{\circ} \mathrm{C}$. 


\section{DISCUSSION}

To what degree, and on what spatial scale, does the thermal environment influence baboon movements? At the large spatial scale of quadrat choice, POST (1978) and ANDERSON (1982) have shown that baboons choose quadrats largely on the basis of food plant availability. ANDERSON (1982) observed that large-scale movements vary over time, and consist of rapid, directed marches which alternate with slower, less-directional displacements. Furthermore, the results of the present study indicate that baboons show little preference among nearby quadrats on the basis of plant cover; at the same time, these quadrats do not represent a random sample of plant distribution across the home range as a whole.

Combining these ideas, it appears that baboons move via directed marches between clusters of quadrats containing favored food plant species. Within a cluster, which can be operationally defined as quadrats lying within a half-hour cruising radius, their movement pattern changes. In this mode, baboons meander in an seemingly undirected fashion, and thereby encounter quadrats roughly in proportion to their occurrence. Most of the time, the net rate of displacement associated with this meandering is relatively constant, and independent of plant cover. At high air temperatures, however, increasing plant cover results in a decrease in baboon movements. This change in group movements represents a change in the way individual baboons respond to clumps of vegetation which they encounter.

When baboons encounter the shade of trees or shrubs under conditions of potential heat gain, they are more likely to stop and rest, and less likely to move on to another location. This small-scale individual response then translates to a change in trajectory for the group as a whole: during hot intervals, baboons meander slowly through regions of dense vegetation. Interestingly, individuals do not specifically seek out shade, but rather adjust their level of movement according to the thermal and microhabitat conditions they encounter in the course of other activities-in essence, opportunistic thermoregulation.

What ecological factors would lead to a subtle, opportunistic mode of thermoregulation? Shaded microhabitats comprise discrete thermal resources for baboons; based on simple foraging models, one would expect animals to prefer locations with deep, abundant shade, i.e., where the benefits of shade are greatest in relation to associated costs. It is therefore somewhat surprising that Amboseli baboons, when subjected to midday heat loads, neither seek out quadrats containing a higher density of shaded microhabitats, nor seek out shaded microhabitats in preference to non-shaded sites. As outlined below, however, this unexpected result rests on several critical thermal and ecological assumptions.

Why do baboons respond to thermal variation at the level of microhabitats rather than quadrats? Recognizing that quadrats in this study differ fundamentally in terms of plant cover, the thermoregulatory impact of quadrat selection depends critically on three assumptions: first, that plant cover translates to shade availability; second, that shade availability translates to cooler temperatures; and third, that between-quadrat thermal differences override non-thermal constraints.

Plant cover equates to shade availability only if baboons encounter shade as a direct function of its proportional area. In the simplest model, this implies a random, constant-rate trajectory through the environment. It seems unlikely that baboons would follow purely arbitrary paths between shade sites when they can potentially use vision and memory to select more-direct routes. If such is the case, then the time required to access individual shade plants may not differ as greatly as one would expect based on differences in plant 
cover alone. Therefore, effective shade availability may change very little as baboons move throughout their environment-a single tree may supply an individuals' shade requirements as effectively as does a forest.

Turning to another vital assumption, does increased shade imply cooler temperatures? Thermal differences between quadrats are in fact not that great when the temperature drop near individual plants is weighted by their percent cover (STELZNER, 1987). Under these circumstances, there may simply be little impetus for between-quadrat thermal preference.

Finally, can non-thermal constraints mask thermal differences? Competing needs such as foraging and predator avoidance may override temperature effects on quadrat choice. For example, INGRAM and LEGGE (1970) observed that young pigs withstand greater cold stress when feeding than otherwise; in addition, NorRIs (1967) concluded that changes in lizard skin coloration represent a compromise between thermoregulation and camouflage.

Combining these ideas, it seems very likely that baboons move through a matrix of quadrats in which differences in temperature and effective shade availability are not as great as differences in food availability. This in turn supports the notion that baboons use microhabitat selection, rather than larger-scale movements, as their primary means of behavioral thermoregulation. If so, however, then the question becomes: why don't baboons spend a greater proportion of time in shade under warm conditions? Part of the answer may relate to the thermal characteristics of baboons.

Adult baboons range in mass from $16.5-33.0 \mathrm{~kg}$ (HALL, 1968) and have a well-developed layer of fur, both factors which reduce the rate of heat transfer between animals and their environment. As a result, changes in body temperature may lag appreciably behind corresponding changes in ambient or blackbulb temperature. Telemetry data from $30 \mathrm{~kg}$ peccaries, for example, shows that daily body temperature attains a maximum $1-4 \mathrm{hr}$ after shade air temperature peaks (PHELPS, 1971). Baboons could exploit thermal time lags by moving alternately between shaded and unshaded microhabitats, as seen in kangaroos (RUSSELL, 1971). Over short time intervals, this scheme would allow the proportion of time spent in shade to remain relatively independent of immediate thermal conditions. The results of this study indicate that baboons may optimize heat dumping while in shade by remaining inactive. On this basis, one would further expect individuals resting in shade to favor open postures promoting heat loss.

An alternative to the observational approach used in this study would be the following: (1) construct precise biophysical models of the thermal characteristics of baboons and their environment; (2) validate model predictions via direct telemetry (i.e., body temperature and surface heat flow) or operative temperature $\left(T_{\mathrm{e}}\right)$ sensors; and (3) predict microhabitat occupancy based on estimated body temperature and its effect on physiological performance (e.g., sprint speed or lethal temperature). This methodology has been successfully applied to reptiles, birds, and small mammals (e.g., Porter \& JAMES, 1979; Kelty \& Lustick, 1977; Chapell et al., 1984; Chapell \& Bartholomew, 1981). The advantages of such an approach are twofold: the results are generalizable, to the extent that the biophysical models can be extended to other species and environments; and the causal relationships are more clearcut between thermal conditions in the environment, on one hand, and body temperature and consequent behavior on the other.

This study, in contrast, involves more exploratory analyses, and focuses more on finescale predictions of behavior, afforded by the excellent field conditions in Amboseli. The predictions are more general in nature than those of a biophysical model, and more specific 
to the baboon/Amboseli system, but are based on the same set of underlying principles. In addition, the conclusions are based on statistical inference from observational data, rather than explicit tests of an energy-balance model. In some ways this may be a more appropriate method for studying a mid-sized mammal in relatively non-extreme environment; thermal constraints are probably rather small, and thermal preferences are thus expressed largely within a sub-lethal thermal envelope.

Given the possibility of heat storage, and time-dependent strategies of microclimate selection, there are numerous behavioral options open to an individual at any given place and time. Under these conditions, one expects that ecological costs associated with thermoregulation (i.e., time spent dumping heat vs. time available for feeding) will be more important than simple avoidance of physiological limits. In this respect, the central problem remains one of finding an appropriate currency to express thermoregulatory costs and benefits (e.g., Altmann, 1974; Tracy \& Christian, 1986). As yet, however, the relationship between fitness, time, and energy remains unclear.

In summary, the features of baboon movements which suggest opportunistic thermoregulation relate in a logical fashion to ecological characteristics of both baboons and their environment. As MOEN (1973) and more recently STEVENSON (1985) have stressed, behavioral mechanisms of thermoregulation influence heat exchange in concert, and can be viewed as a hierarchy. For baboons, this corresponds to a series of contingent decisions, ranging from high-order to low-order: (1) choose habitat; (2) choose microhabitat; (3) choose activity; and (4) choose posture and body orientation. This study, as well as related work (STELZNER \& HAUSFATER, 1986), indicates that yellow baboons respond to potential thermal stress primarily by means of fine-scale adjustments in posture and activity, not through changes in higher-order patterns of behavior.

\section{CONCLUSIONS}

(1) Baboons select quadrats lying within a half-hour travel radius at random with respect to plant cover. Specifically, baboons do not prefer quadrats with greater apparent shade availability, under midday heat loads.

(2) Spatial displacement rates vary inversely with plant cover under hot, but not moderate or cool, conditions.

(3) Baboons in shaded locations move less, and rest more, at high temperatures than at low temperatures. Individuals do not prefer shaded over non-shaded microhabitats at high temperatures; instead, these animals appear to adjust their behavior in response to opportunistic encounters with shade.

\section{REFERENCES}

AdAIR, E. R., 1977. Skin, preoptic and core temperatures influence behavioral thermoregulation. J. Appl. Physiol., 42: 559-564.

\& B. A. WRIGHT, 1976. Behavioral thermoregulation in the squirrel monkey when response effort is varied. J. Comp. Physiol. Psychol., 90: 179-184.

Alcock, J., 1979. Animal Behavior (2nd ed.). Sinauer, Sunderland, Massachusetts.

AltmanN, J., 1974. Observational study of behavior: sampling methods. Behaviour, 49: 227-267.

Altmann, S. A., 1974. Baboons, space, time, and energy. Amer. Zoologist, 14: 221-248.

\& J. Altmann, 1970. Baboon Ecology. Univ. of Chicago Press, Chicago. 
Anderson, D. J., 1982. Patterns of space utilization. Ph.D. thesis. Univ. of Washington.

BAKKEN, G. S., 1976. A heat transfer analysis of animals: unifying concepts and the application of metabolism chamber data to field ecology. J. Theor. Biol., 60: 337-384.

BERNSTEIN, I. S., 1972. Daily activity cycles and weather influences on a pigtail monkey group. Folia Primatol., 18: 390-415.

1975. Activity patterns in a gelada monkey group. Folia Primatol., 23: 50-71.

1976. Activity patterns in a sooty mangabey group. Folia Primatol., 26: 185-200.

Cabanac, M., 1975. Temperature regulation. Ann. Rev. Physiol., 37: 415-435.

CampBell, G. S., 1977. An Introduction to Environmental Biophysics. Springer-Verlag, New York.

Chappell, M. A. \& G. A. Bartholomew, 1981.'Standard operative temperatures and thermal energetics of the antelope ground squirrel (Ammospermophilus leucurus). Physiol. Zool., 54: 81-93.

- D. L. Goldstein, \& D. W. WinkLER, 1984. Oxygen consumption, evaporative water loss, and temperature regulation of California gull chicks (Larus californicus) in a desert rookery. Physiol. Zool., 57: 204-214.

Charnov, E., 1976. Optimal foraging, the marginal value theorem. Theor. Pop. Biol., 9: 129-136.

Clark, P. J. \& F. C. Evans, 1954. Distance to the nearest neighbor as a measure of spatial relationships in populations. Ecology, 35: 445-453.

CortaM, G \& J. T. CuRTIs, 1956. The use of distance measures in phytosociological sampling. Ecolo$g y, 37: 449-460$.

DAHL, J. F., I. S. BERNSTFIN, \& L. WILliams, 1982. Thermoregulation and social structure of a captive group of rhesus macaques. Int. J. Primatol., 3: 273.

\& E. O. SMITH, 1985. Assessing variation in the social behavior of stumptail macaques using thermal criteria. Amer. J. Phys. Anthropol., 68:467-477.

Dewoskin, R., 1980. Heat exchange influences on foraging behavior of Zonotrichia flocks. Ecology, $61: 30-36$.

Euzondo, R., 1977. Temperature regulation in primates. In: Int. Rev. Physiol. Environ. Physiol. II. Vol. 5, D. Robertshaw (ed.), University Park Press, Baltimore, pp. 71-118.

Folk, B., 1966. An Introduction to Environmental Physiology. Lea \& Feabiger, Philadelphia.

Funkhouser, G. E., E. A. Higgins, T. AdAM, \& C. C. SNOw, 1967. The response of the savannah baboon (Papio cynocephalus) to thermal stress. Life Sci. Oxford, 6: 1615-1620.

GATES, D. M., 1980. Biophysical Ecology. Springer-Verlag, New York.

GATES, J. E. \& D. M. HARMAN, 1980. White-tailed deer wintering area in a hemlock-northern hardwood forest. Can. Field-Nat., 94: 259-268.

Grieg-Smith, P., 1965. Quantitative Plant Ecology (2nd ed.). Butterworth \& Co., London.

Griffiths, J. W., 1969. Climate. In: East Africa: Its Peoples and Resources, W. T. W. MoRgan (ed.), Survey of Kenya, Nairobi, pp. 107-118.

HARDING, R. S. O., 1976. Ranging patterns of a troop of baboons (Papio anubis) in Kenya. Folia Primatol., 25: 143-185.

Hausfater, G., 1975. Dominance and Reproduction in Baboons: a Quantitative Analysis. S. Karger, Basel.

HeLleR, H. C. \& D. M. GATES, 1971. Altitudinal zonation of chipmunks (Eutamias): energy budgets. Ecology, 52: 424-433.

Hiley, P. H., 1976. The thermoregulatory responses of the galago (Galago crassicaudatus), the baboon (Papio cynocephalus) and the chimpanzee (Pan satyrus) to heat stress. J. Physiol. (Lond.), 254: 657-671.

Huey, R. B. \& M. Slatkin, 1976. Costs and benefits of lizard thermoregulation. Quart. Rev. Biol., $51: 363-384$.

INGRAM, D. L. \& K. F. LEGGE, 1970. The thermoregulatory behavior of young pigs in a natural environment. Physiol. Behav., 5: 981-987.

IWAMOTO, T. \& R. DUNBAR, 1983. Thermoregulation, habitat quality and the behavioural ecology in gelada baboons. J. Anim. Ecol., 53: 357-366.

KeLty, M. P. \& S. I. Lustick, 1977. Energetics of the starling (Sturnus vulgaris) in a pine woods. Ecology, 58: 1181-1185.

MoEn, A. N., 1973. Wildlife Ecology: An Analytical Approach. W. H. Freeman, San Francisco.

MorhardT, S. S. \& D. M. GATES, 1974. Energy-exchange analysis of the Belding ground squirrel and its habitat. Ecol. Monogr., 44: 17-44.

Mueller-DomboIs, D. \& H. Ellenberg, 1974. Aims and Methods of Vegetation Ecology. John Wiley \& Sons, New York. 
Newman, C. M., E. G. Cummings, J. L. MilleR, \& H. Wright, 1970. Thermoregulatory responses of baboons exposed to heat stress and scopalamine. Physiologist (Wash.), 13:271.

NORRIS, K. S., 1967. Color adaptation in desert reptiles and its thermal relationships. In: Lizard Ecology, a Symposium, W. W. Milstead (ed.), Univ. of Missouri Press, Columbia, Missouri, pp. $162-229$.

PhelPS, J., 1971. Behavioral thermoregulation in the javelina (Tayassu tajacu). M. S. thesis, Univ. of Arizona.

PORTER, W. P. \& F. C. JAMES, 1979. Behavioral implications of mechanistic ecology II: the African rainbow lizard, Agama agama. Copeia, 1979: 594-619.

- J. W. Mitchell, W. A. Beckman, \& C. B. Dewitt, 1973. Behavioral implications of mechanistic ecology. Oecologia (Berlin), 13: 1-54.

\& C. R. TRACY, 1983. Biophysical analyses of energetics, time-space utilization, and distributional limits of lizards. In: Lizard Ecology: Studies of a Model Vertebrate, R. B. HueY, E. R. Pianka, \& T. W. Schoener (eds.), Harvard Univ. Press, Cambridge, Massachusetts, pp. 55-83.

Post, D., 1978. Feeding and ranging behavior of the yellow baboon (Papio cynocephalus). Ph.D. thesis, Yale Univ., New Haven.

$\longrightarrow$, G. Hausfater, \& S. A. McCuskey, 1980. Feeding behavior of yellow baboons (Papio cynocephalus): relationship to age, gender, and dominance rank. Folia Primatol., 34: 170-195.

Russell, E. M., 1971. Changes in behaviour with temperature in the red kangaroo, Megaleia rufa. Aust. J. Zool., 19: 207-213.

SHARMAN, M., 1980. Feeding, ranging, and social organization of the Guinea baboon (Papio papio) in Senegal. Ph.D. thesis, Univ. of St. Andrews, Scotland.

Slatkin, M. \& G. Hausfater, 1976. A note on the activity of a solitary male baboon. Primates, 17 : $311-322$.

StelzNer, J. K., 1987. Thermal environment and behavior of yellow baboons. Ph.D. thesis, Cornell Univ.

\& G. HAusfater, 1986. Posture, microclimate, and thermoregulation in yellow baboons. Primates, 17: 449-463.

Stevenson, R. D., 1985. The relative importance of behavioral and physiological adjustments controlling body temperature in terrestrial ectotherms. Amer. Naturalist, 126: 362-386.

Stolz, L. P. \& G. S. SAYMAnN, 1970. Ecology and behavior of baboons in the Northern Transvaal. Ann. Transvaal Mus., 26: 99-143.

Telfer, E. S., 1970. Winter habitat selection by moose and white-tailed deer. J. Wildl. Manag., 34: $553-559$.

Tracy, C. R. \& K. A. Christian, 1986. Ecological relations among space, time, and thermal niche axes. Ecology, 67: 609-615.

Warde, W. \& J. W. Petranka, 1981. A correction factor table for missing point-center quarter data. Ecology, 62: 491-494.

Western, D., 1972. The structure, dynamics, and change of the Amboseli ecosystem. Ph.D. thesis, Univ. of Nairobi.

\& C. van PraEt, 1973. Cyclical changes in the habitat and climate of an African ecosystem. Nature (Lond.), 241: 104-106.

Zervanos, S. M. \& N. F. Hadley, 1973. Adaptational biology and energy relationships of the collared peccary (Tayassu tajacu). Ecology, 54: 759-774.

-Received October 22, 1986; Accepted July 4, 1987

Author's Name and Address: Jefrerey K. StelzNer, Physics Department B-019, University of California, San Diego, La Jolla, California 92093, U.S.A. 